\title{
С. Купn-Сазонов
}

\section{КТО ТАКИЕ ЗАГАДОЧНЫЕ МЫ В РУССКОМ И ЭСТОНСКОМ ЯЗЫКАХ? (О ПЕРЕНОСНОМ УПОТРЕБЛЕНИИ ФОРМ 1-ГО ЛИЦА МНОЖЕСТВЕННОГО ЧИСЛА)}

Статья посвящена переносному употреблению форм 1-го лица мн. ч. в русском и эстонском языках. Некоторые случаи переносного употребления встречаются в русском языке регулярно, однако они не столь распростране-

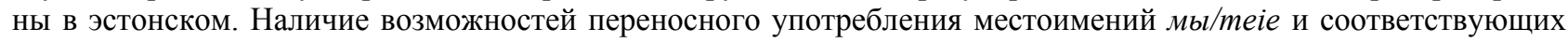
глагольных форм зависит от культурных и языковых традиций рассматриваемых языков. В статье проанализированы некоторые случаи переносного употребления, такие как «королевское мы», «авторское мы», «мы подобострастия», «докторское мы», «материнское мы» и др.

Отметим, что такие случаи переносного употребления могут вызвать некоторые трудности в изучении языка, а также в процессе перевода. Анализ позволяет прийти к выводу, что в русском языке форма 1-го лица мн. ч. может в определенных контекстах «заменить» любые другие личные местоимения и соответствующие глагольные формы, в эстонском же языке наблюдаются некоторые ограничения. При изучении языка и особенно при переводе важно помнить об этих различиях.

Ключевые слова: местоимения, переносное употребление, русский язык, эстонский язык.

DOI: $10.35634 / 2224-9443-2020-14-1-34-44$

Личные местоимения - одна из первых тем, с которой знакомится каждый изучающий иностранный язык ${ }^{1}$. Э. Бенвенист утверждает, что местоимения во всех языках делятся на одни и те же разряды (личные, указательные и др.). В силу универсальности этих слов местоимения можно рассматривать как общелингвистическую проблему, так и как проблему конкретного языка [Бенвенист 2002, 258].

В русской и эстонской грамматиках местоимения неоднократно заслуживали внимание разных языковедов, например, П. Гард [1985], М. А. Шелякин [1986], Русские местоимения... [1989], Р. Поол [1999], Н. А. Герасименко [2003], Л. Х. Головенкина [2004], Б. Ю. Норман и А. М. Плотникова [2016], Р. Паюсалу [1999; 2009], Э. Кайсер и К. Хийетамм [2004], Л. Линдстрём [2009] и многие другие. В частности, употреблению и функциям местоимения 1-го лица мн. ч. в русском языке посвящены исследования 3. М. Мурыгиной [1970, 64-70], Р. Пююкко [2002, 233-248], И. Ю. Граневой [2010], Б. Нормана и А. Плотниковой [2016]. В эстонской лингвистике пока нет специальных исследований, в которых рассматривались бы отдельно местоимение 1-го лица мн. ч. теіе и соответствующие глагольные формы. До сих пор пока еще мало сопоставительных исследований русских и эстонских местоимений, но всё же эта тема затрагивалась в некоторых трудах: см., напр., Кюльмоя и др. [2003, 71-76], Р. Блокланд и П. Кехайов [2010], В. П. Щаднева и Е. М. Вельман-Омелина [2016] и др.

Цель нашей статьи - попытка сопоставить употребление местоимений 1-го л. мн. ч. в русском и эстонском языках, при этом особое внимание уделив их переносному употреблению. В ходе анализа попытаемся выявить основные различия между рассматриваемыми языками и выяснить возможные причины расхождений с учетом возможных экстралингвистических факторов.

В рассматриваемых языках системы личных местоимений во многом сходны, существуют лишь некоторые отличия. Одно из расхождений обусловлено обстоятельством, что в эстонском языке нет грамматической категории рода ${ }^{2}$, поэтому 3 -е л. ед. ч. представлено одной лексемой tema, которая может обозначать как мужчину, так и женщину. Необходимо также отметить, что существует уменьшительно-ласкательный дериват temake, употребляемый по отношению к женщине, однако его нельзя считать нейтральным, и потому, хотя он встречается в художественной литературе и в разговорной речи, его невозможно употребить в официальных документах или в официальном стиле в целом ${ }^{3}$.

\footnotetext{
${ }^{1}$ Хотя местоимения, как правило, считаются универсальной грамматической категорией, однако В. Гиббс утверждает, что в языке ика в Северной Колумбии отсутствует система личных местоимений [Gibbs 2002, 84].

${ }^{2}$ В большинстве языков мира у личных местоимений нет категории рода, см. [Siewierska 2013].

${ }^{3}$ Более подробно об этом см. [Kupp-Sazonov 2013, 108-112].
} 
Кроме того, эстонские личные местоимения имеют две формы: полную и неполную (например: mina/ma - я). Полная используется, когда подчеркивается само местоимение (чаще всего субъект действия), а неполная выбирается, когда акцентируется само действие.

Сходными категориями личных местоимений в рассматриваемых языках являются категории числа, лица и падежа.

Как уже сказано, в нашей статье будет обсуждаться переносное употребление местоимения Mbl/meie и соответствующих форм глаголов, так как русские (а также эстонские - наше дополнение) глагольные формы 1-го л. мн. ч. могут встречаться в тексте и без сопутствующего личного местоимения, однако их значение в принципе включает в себя семантику 'мы' [Норман 2002, 217].

Термин переносное употребление грамматической формы означает, что одна форма встречается в контексте, типичном для другой формы, при этом не отменяется ее грамматическое значение. Форму, употребляемую переносно, можно заменить другой формой в прямом употреблении [Бондарко 1971a, 173]. Например, форма наст. вр. может употребляться не только для выражения временного плана настоящего, но также для обозначения действия или состояния в прошлом или в будущем. В частности, в повествованиях часто встречается так называемое настоящее историческое ${ }^{4}$, что означает употребление формы настоящего времени для выражения семантического плана прошлого [Declerck 2006, 27] $]^{5}$.

(1) Вчера в полночь прохожу через столовую, а там свеча горит. (А. Чехов)

Кроме грамматических категорий времени и вида, переносное употребление форм может проявляться также в категориях числа и лица ${ }^{6}$.

\section{2. Общее значение форм 1-го лица множественного числа}

Прежде чем перейти непосредственно к переносному употреблению, следует коротко рассмотреть прямое или абсолютное употребление форм 1-го л. мн. ч. Итак, общее значение местоимений Mbl/meie - это говорящий + еще кто-то; при этом, под кем-то могут подразумеваться один человек (2), несколько человек или много людей (3) или все люди на Земле (4).

(2а) - Однако мы заговорились, дорогой Фагот, а публика начинает скучать.

(2б) „Me oleme pikalt vestlema jä̈̈nud, kulla Fagott, vaatajatel hakkab igav.“

(М. Булгаков)

(3а) - Мы не валютчики, - раздались отдельные обиженные голоса (М. Булгаков)

(3б), ,Me ei ole vaalutahaid,“ kostis saalist üksikuid solvunud hääli

(4а) Мы должны защищать окружающую среду.

(4б) Me peame kaitsma ümbritsevat keskkonda.

Об общем значении местоимения мыс см. [Гранева 2008, 207].

Иногда, даже в контексте, бывает трудно определить, кто подразумевается под местоимениями мыl/meie. Например, в романе М. Булгакова «Мастер и Маргарита» редактор литературного журнала Михаил Берлиоз отвечает на вопрос сатаны о том, верят ли они в бога, следующим образом:

(5а) - Да, мы не верим в бога, - чуть ульюбувшись испугу интуриста, ответил Берлиоз.

(5б) „Jah, me ei usu Jumalat, “vastas Berlioz välisturisti ehmatuse üle muiates..

(М. Булгаков)

В обоих языках существуют, по крайней мере, два способа для интерпретации слов Берлиоза. С одной стороны, местоимения $\mathrm{mbl} / \mathrm{meie}$ могут указывать на Берлиоза и поэта Бездомного, который разделяет идеи своего товарища и также участвует в этой беседе; однако, с другой стороны, местоимение 1-го л. мн. ч. может иметь семантику 'советские люди': поскольку в Советском Союзе иногда

\footnotetext{
${ }^{4}$ Подробнее о терминологии см. [Уржа 2015].

${ }^{5}$ О настоящем историческом писали многие лингвисты, см., например, [Виноградов 1972: 451], [Бондарко 1971: 142] и др.

${ }^{6}$ Об одном случае переносного употребления формы 3-го л. мн. ч. в русском и эстонском языках см. [КуппСазонов 2016, 301-302].
} 
преследовали верующих, поэтому многие люди не признавали открыто, что верят в бога, и часто утверждали обратное.

М. Даниэль предполагает, что в соответствии с традиционной типологией можно выделить три разных типа местоимений 1-го л. мн. ч.

1. «Мы-нейтральное», включающее или исключающее.

2. «Мы-инклюзивное», включающее адресата.

3. «Мы-эксклюзивное», исключающее адресата.

Если в языке нет первого, значит в нем существует противопоставление второго и третьего 7 [Даниэль 2002, 239]. Русское и эстонское местоимения Mbl/meie можно отнести к первому типу, т. е. к «нейтральному мы». В примерах $(6 \mathrm{a}, 6 б)$ адресат включен, так как Коровьев объясняет Маргарите, что они увидят на балу.

(6а) Бал будет пышный /.../ Мы увидим лии, объем власти которых в свое время был чрезвычайно велик. (М. Булгаков)

(6б) Ball tuleb uhke /.../Me näeme isikuid, kelle võimu ulatus oli omal ajal tohutu.

В той же беседе можно найти контекст $(7 \mathrm{a}, 76)$, в котором адресат исключен, говоря «мы», Коровьев не подразумевает Маргариту, а только свиту Воланда.

(7а) Сто двадиать одну Маргариту обнаружили мы в Москве... (М. Булгаков)

(7б) Leidsime Moskvast sada kakskümmend üks Margaritat...

Примеры (5a, 5б) можно рассматривать как смешанный случай, так как в беседе участвуют три персонажа, и с одной стороны «мы», употребляемое Берлиозом, включает его товарища Ивана Бездомного, однако, с другой стороны, исключает второго собеседника - Воланда.

\section{3. Переносное употребление форм 1-го лица множественного числа}

Сопоставляя прямое употребление форм 1-го л. мн. ч. в русском и эстонском языках, можно прийти к выводу, что особых различий при этом не наблюдается. Далее обратимся непосредственно к анализу случаев переносного употребления этих форм.

\subsection{1-е лицо мн. ч. заменяет 1-е лицо ед. ч.}

В русском языке в некоторых случаях $м b l$ может употребляться вместо $я$, и при этом цели говорящих могут быть совершенно противоположными, от выражения своей величественности, важности и авторитетности («королевское мы») до крайнего умаления («мы подобострастия») ${ }^{8}$.

\subsubsection{Pluralis majestatis или «королевское мы»"}

Это переносное употребление встречается, скорее всего, во всех языках, носители которых являлись или являются подданными монархов. Русский язык входит в число языков, для которых речь царей - это неотъемлемая часть истории. Эстонский язык находится немного в ином положении, так как в Эстонии никогда не было своего собственного монарха, но Эстония в разные исторические периоды входила в состав разных королевств и ею управляли иностранные государи - шведские, русские, датские, польские и др. Думается, что именно поэтому в эстонском языке не существует лингвистической и культурной традиций употребления «королевского мы». Однако можно утверждать, что имеется переводческая традиция, так как именно в переводах «королевское мы» встречается и в эстонском языке.

\footnotetext{
${ }^{7}$ И. Ю. Гранева предлагает различать референтное и нереферентное употребление местоимений, в случае местоимения $\mathbf{M b l}$ «главным критерием разграничения «референтного» и «нереферентного» $\mathrm{Mbl}$ является его употребление или по отношению к лицам, которые являются непосредственными участниками коммуникации (и тем самым могущими стать объектами конкретной референции), или по отношению к неопределенному множеству лиц, не участвующих в акте коммуникации непосредственно» [Гранева 2008, 208$].$

${ }^{8}$ См. [Виноградов 1972, 351].

${ }^{9} \mathrm{~B}$ эстонском языке это явление носит название majesteedi mitmus (дословно множественность величества) [Erelt 1990, 37].
} 
(8а) - Секретарь! Мы божиею милостью определяем сержанта Николаева для начала в помочники тебе... (В. Шишков)

(8б) ,Sekretär! Jumala armust meie määrame seersant Nikolajevi esialgu sinu abiliseks... “

\subsection{2. «Авторское мы»}

«Авторское мы» (иногда выделяют еще «редакторское мы») встречается, прежде всего, в научных и публицистических текстах, в контекстах, где по логике должно употребляться местоимение 1-го л. ед. ч., так как автором текста на самом деле является один человек.

Необходимо отметить, что следует различать «чистое» авторское мы и такое, которое больше тяготеет к «мы-инклюзивному».

(9а) Вспомним стих из уже прочитированного нами стихотворения А. Блока...

(96) Tuletame meelde A. Bloki värsirida, mida oleme juba tsiteerinud..

(Ю. Лотман)

Глагольные формы вспомним/tuletame meelde служат одной цели: автор употребляет их, чтобы установить контакт со своими читателями, привлечь его в свою научную дискуссию. К такой цели не стремятся слова процитированного нами/oleme tsiteerinud, они относятся действительно только к автору текста, так как читатель ничего не цитирует. Здесь наблюдается как раз классический случай «авторского мы», которым выражается скромность автора, часто таким образом подчеркивающего роль предыдущих, нынешних и, возможно, даже будущих коллег в своей научной работе, чем выражаются благодарность и уважение. В русском научном стиле это довольно частотное явление, иногда даже в устных выступлениях.

В современном эстонском языке употребление местоимения теіе и соответствующих глагольных форм считается приемлемым только в том случае, если текст имеет более одного автора [Erelt 1990, 37]. Однако пример (9б) доказывает, что при переводе это правило иногда игнорируется.

\subsection{3. «Мы подобострастия или умаления»}

Термин «мы подобострастия или умаления» был предложен М. А. Шелякиным, по его словам, к такому переносному употреблению прибегали крестьяне и другие люди из низких слоев общества в дореволюционные времена [Шелякин 1986, 16-17]. «Мы подобострастия» проявляется в ситуациях, когда общаются люди с разными социальными статусами.

(10a) - Возьмите, барин, задешево отдам. Ломаденка стала совсем.

- Да ты откуда?

- Мы из деревни. Свои дрова, хорошие, сухие. (Л. Толстой)

(10б) ,Võtke, härra, annan odavalt ära. Hobusekronu ei liigu enam paigastki. “ „Kust sa oled?“

„Oleme maalt. Omad puud, head, kuivad. “

(11а) Протасов. А... вы - замужняя?

Луша. Нет еще... девицы мын... (М. Горький)

(11б) Protassov: Kas te ... olete abielus?

Luša: Ei, veel ei ole...me oleme neiud...

Данное переносное употребление форм 1-го л. мн. ч. можно рассматривать как противоположное «королевскому мы». В случае Pluralis majestatis величественность одного человека выражается формами множественного числа, так как кажется, что для него единственного числа будет недостаточно. Однако в случаях «мы подобострастия или умаления» человек считает себя настолько незначительным, что по своему мнению, не заслуживает даже того, чтобы говоря о себе, употреблять местоимение «я».

Относительно эстонского языка, следует отметить, что эстонские лингвисты в своих трудах не упоминают об этой возможности переносного употребления форм 1-го л. мн. ч. Кроме того, принимая во внимание экстралингвистические факторы (как и в случае «королевского мы»), важно помнить, что в Эстонии никогда не было эстоноязычного дворянства, большинство эстонцев в течение веков были в основном крестьянами, поэтому вряд ли подобные беседы, представленные в примерах (10) и (11) могли проходить на эстонском языке. Тем не менее это употребление встречается в пере- 
водах; при этом, как правило, тексты относятся к середине XX века (пример 106 взят из перевода романа, опубликованного в 1958-м году, 116 из книги 1959-го г.).

\subsection{1-е лицо мн. ч. заменяет 2-ое лицо ед. или мн. ч.}

Замена форм 1-го л. ед. ч. формами 1-го л. мн. ч. характеризует, прежде всего, отношение говорящего к себе (считает ли он себя чрезвычайно важным, или наоборот ничтожным; выражается желание подчеркнуть могущество или скромность). В то же время, заменяя формы 2-го л. ед. или мн. ч. формами 1-го л. мн. ч., говорящий выражает свое отношение к собеседнику/собеседникам.

\subsection{1. «Докторское мы»}

Название этого типа переносного употребления формы 1-го л. мн. ч. следует понимать с некоторыми оговорками, так как оно встречается не только в разговорах врача с пациентом. На это указывает и то обстоятельство, что в трудах разных лингвистов оно называется по-разному, например, «сочувственно-интимное» [Аванесов, Сидоров 1945, 154], «докторское, родительское» [Красильникова 1990, 9], «инклюзивное» [Апресян 1995, 153], «солидарное» [Булыгина, Шмелев 1997, 327] и т. д. В целом можно утверждать, что подобное употребление, как правило, встречается в ситуациях, в которых одно лицо обладает более высоким статусом, чем его собеседник. Т. В. Булыгина и А. Д. Шмелев

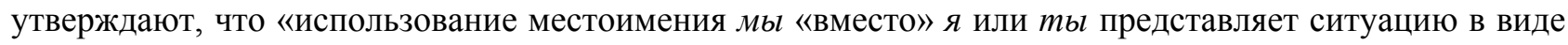
такой, в которой в равной мере участвуют говорящий и адресат. То, о чем говорится, представлено как общая проблема; выражается значение солидарности, равноправия〉 [Булыгина, Шмелев 1997, 332-333]. Однако при этом необходимо иметь в виду, что отношение говорящего к адресату может быть очень разным. Например, в ситуации медицинского осмотра, врач в беседе с пациентом может таким образом действительно выражать сочувствие и солидарность (12а, 12б):

(12а) Цой /.../ имел вид настоящего /.../ врача. Он быстро подошел к койке зоолога: - Как дела, Арсен Давидович? Как мы себя чувствуем? (Г. Адамов)

(12б) Tsoi /.../ nägi välja nagu tõeline /.../ arst. Ta astus kiiresti zooloogi voodi juurde: „Kuidas läheb, Arsen Davidovitš? Kuidas me end tunneme? “

Однако думается, что это только одна сторона медали и спектр нюансов, выражаемых этим переносным употреблением местоимения 1-го л. мн. ч., намного шире, так как не во всех случаях наблюдаются сочувствие, солидарность и т. п. Ю. Д. Апресян подчеркивает, что целью такого обращения к собеседнику может являться также критика [Апресян 1995, 153], см. (13):

(13а) Он молча повесил шинель на гвоздь. Сейчас и мать выскажется.

- Так и будем теперь хозяйствовать? - спросила она. - Что

имеем, по людям раздадим, совхоз развалим? (В. Панова)

(136) Korosteljov riputas sineli vaikides nagile. Küllap emagi kohe rääkima hakkab. „,Niimoodi me hakkame siis majandama?" küsis ema. „Kõik, mis on, jagame rahvale välja, sohvoosi aga laastame ära? “

В разговоре взрослых с детьми (учитель и ученик, родитель и ребенок и др.) может выражаться также критика, но и ирония, см. пример (14).

(14а) Снова мы не выполнили домашнее задание, не так ли?

(14б) Me pole jälle kodust ülesannet ära teinud, kas pole nii?

О сочувствии или солидарности не приходится говорить также тогда, когда такое переносное употребление местоимения $\mathbf{M b l}$ встречается в речи представителей других профессий, например, милиционеров (15), судей [Санников 2002, 79-80], начальников (16) и др., обладающих определенной властью по отношению к своим собеседникам.

(15а) В секретарскую спокойной деловой походкой входила милиция в составе двух человек /.../ - Давайте не будем рыдать, гражданка, - спокойно сказал первызи... (М. Булгаков)

(15б) Rahulikult ja asjalikult astusid sekretäri tuppa miilitsatöötajad kahes isikus.

„,Jätke nutmine, kodanik, “ ̈̈tles esimene mees rahulikult. 
Думается, что употребление формы 1-го л. мн. ч. смягчает слова милиционера, который мог бы также сказать: «Прекратите/прекращ⿻айте pыдать!» (приблизительно так это переведено на эстонский язык) или совсем резко и грубо «Не рыдать!». В эстонском языке представляется возможным также вариант с формой 1-го л. мн. ч. например: Kodanik, ärme nü̈̈ nuta. ${ }^{10}$

(16а) - Значит, будем играть в молчанку? - наконец сказал Начальник...

(16б) ,Nii et mängime vaikimise mängu? “ küsis Ülem viimaks...

(Ф. Искандер)

\subsection{2. «Мы обслуживающего персонала» ${ }^{11}$}

По словам эстонского лингвиста Мати Эрелта, мыз в речи обслуживающего персонала (продавца, парикмахера, официанта и др.) с клиентом имеет функцию позитивной вежливости ${ }^{12}$, т. е. говорящий демонстрирует свою готовность выполнять желания клиента [Erelt 1990, 35-36].

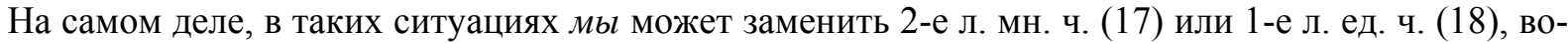
прос: Что будем пить? - можно легко переформулировать: Что вы будете пить? - так как бармен не имеет в виду себя. А под вопросом парикмахера: Какую прическу будем делать? - подразумевается: Какую прическу буду делать? - так как клиент на самом деле в этом процессе не участвует.

(17) - Что будем пить? - повернулся к ним бармен. (А. Геласимов)

(18) - Какую прическу будем делать? - традиционный вопрос парикмахера.

(Г. Яворская)

Эстонский язык также допускает такое переносное употребление, бармен может спросить: Mida me täna joome? - и парикмахер может задать вопрос: Millise soengu me teeme?

\subsection{1-е лицо мн. ч. заменяет 3-е лицо ед. или мн. ч.}

Так называемое «материнское мы» свойственно, прежде всего, именно матерям ${ }^{13}$; хотя, кроме маленьких детей, таким же образом иногда говорят о своих пожилых родственниках или даже о домашних любимцах - т. е. о тех, о ком взрослый человек заботится и за кого несет ответственность.

Это переносное употребление встречается и в письменных текстах, и в устном общении. Думается, что в эстонском языке оно не так широко распространено, как в русском; тем не менее, примеры такого употребления есть в обоих языках (20) и (21).

(20) Нам сейчас 5 месяцев, чешем зубки всем, что попадается под руку. (Мамочки ВY) $)^{14}$

(21) Meil ole veel ka ühtegi hammast ...poja on 6 kuud ja 18 päeva vana. (Naistekas)

Необходимо подчеркнуть, что «материнское мы» существенно отличается от так называемого «беби-тока» (по-английски baby talk) ${ }^{15}$, когда взрослый человек разговаривает не о ребенке, а с ним. Американский лингвист Дороти Уиллс [Willis 1977] выделяет две разновидности «беби-тока», см. примеры (22) и (23):

(22) We'll just clean your toothies. (Мы почистим твои зубки/Me peseme su kikud puhtaks)

(23) We're going to have a bath now. (Теперь мы пойдем купаться в ванну/Nüӥd läheme vanni)

Очевидно, что в примере (22) мы относится, прежде всего, к взрослому, а в предложении (23) к ребенку, хотя оба эти действия (чистка зубов и принятие ванны) включают до определенной степени как взрослого, так и ребенка. Конечно, в ванне будет купаться ребенок и именно его зубки необходимо почистить, но эти действия не были бы выполнены без присутствия взрослого. Поэтому есть

\footnotetext{
${ }^{10} \mathrm{~B}$ эстонском языке в повелительном наклонении употребляется специальная отрицательная частица ӓra, которая в эстонской лингвистике рассматривается как глагол с неполной парадигмой, так как она изменяется по лицам. Например: 2-е л. ед. ч. ӓra и 2-е л. мн. ч. ̈̈rge и т. д.

${ }^{11}$ Например, К. Филлипс называет такое $м b l$ «sartorial we» [1984, 93].

12 О теории вежливости см. [Brown, Levinson 1987].

${ }^{13}$ Недавно автору статьи довелось услышать подобное употребление формы $\boldsymbol{M b l}$ и с уст русскоговорящего молодого отца.

${ }_{14}$ Сохранено написание, приведенное на сайте.

${ }^{15}$ О терминологии см. [Blackwell 2007].
} 
основание рассматривать такие случаи употребления форм 1-го л. мн. ч. в какой-то степени как «мыинклюзивное», что нельзя сказать о «материнском мы», так как фраза нам сейчас 5 месяцев, никаким образом не может относиться к взрослому, произносящему эти слова.

\section{4. Выводы}

В заключение отметим, что русский язык допускает замену всех форм лица и числа формами 1го л. мн. ч. В эстонском языке некоторые из случаев переносного употребления встречаются в основном в текстах перевода и не столь характерны для эстонского языка, причинами являются в том числе и экстралингвистические факторы. Результаты анализа представлены в таблице.

Переносное употребление форм 1 лица множественного числа в русском и эстонском языках

\begin{tabular}{|l|c|c|}
\hline Переносное употребление & Русский язык & Эстонский язык \\
\hline $\begin{array}{l}1 \text { л. мн. ч. вместо 1-го л. ед. ч. } \\
\text { («королевское мы») }\end{array}$ & + & $+/-$ в переводных текстах) \\
\hline $\begin{array}{l}1 \text { л. мн. ч. вместо 1-го л. ед. ч. } \\
\text { («авторское мы») }\end{array}$ & + & $+/-$ (в переводных текстах) \\
\hline $\begin{array}{l}1 \text { л. мн. ч. вместо 1-го л. ед. ч. } \\
\text { «мы подобострастия или умаления») }\end{array}$ & + & + (в переводных текстах) \\
\hline $\begin{array}{l}1 \text { л. мн. ч. вместо 2-го л. ед. или мн. ч. } \\
\text { (щдокторское мы») }\end{array}$ & + & + \\
\hline $\begin{array}{l}1 \text { л. мн. ч. вместо 2-го л. ед. или мн. ч. } \\
\text { («мы обслуживающего персонала») }\end{array}$ & + & + \\
\hline $\begin{array}{l}1 \text { л. мн. ч. вместо 3-го л. ед. или мн. ч. } \\
\text { (материнское мы») }\end{array}$ & $\begin{array}{c}\text { (встречается } \\
\text { регулярно) }\end{array}$ & менее регулярно) \\
\hline
\end{tabular}

Так как различия в переносном употреблении форм 1-го л. мн. ч. в русском и эстонском языках могут вызывать некоторые трудности при изучении языка, а также в процессе перевода, их нужно иметь в виду, переводя или преподавая русский и эстонский языки как неродные.

\section{ИСТОЧНИКИ}

Адамов Г. Б. Тайна двух океанов. М., 1954. 480 с.

Булгаков М. А. Мастер и Маргарита. Рассказы. М., 1980. 480 с.

Геласимов А. В. Дом на Озерной. М.: Эксмо, 2009. 253 с.

Горький М. Пьесы, драматические наброски 1897-1906. М., 1970. 687 с.

Лотман Ю. М. Структура художественного текста. М., 1970. 380 с.

Мамочки BY https://mamochki.by/forum/13/171625/u_nas_rejutsya_zubkino_nam_vse.html (дата обращения: 13.06.2019)

Панова В. Ф. Ясный берег. Л.: Молодая гвардия, 1950. 230 с.

Толстой Л. Н. Собрание сочинений в четырнадцати томах. Том двенадцатый. Повести и рассказы $1889-$ 1904. M., 1953. 314 c.

Чехов А. П. Пьесы. М.: Художественная литература, 1982. 301 с.

Шииков В. Я. Емельян Пугачев: историческое повествование. Книга вторая. М., 1962. 847 с.

Яворская Г. Бигуди и «сорока» // Юность. 1965. № 7.

Adamov G. Kahe ookeani saladus. Tallinn: Eesti Riiklik Kirjastus, 1957. 471 c.

Bulgakov M. Meister ja Margarita. Tallinn, 1995. $335 \mathrm{c}$.

Gorki M. Näidendid 1901-1906. Tallinn, 1959. 584 c.

Lotman J. Kunstilise teksti struktuur. Tallinn, 2006. $573 \mathrm{c}$.

Naistekas http://naistekas.delfi.ee/foorum/read.php?32,8230682 (дата обращения: 13.06.2019)

Panova V. Helge kallas. Tallinn: Eesti Riiklik Kirjastus, 1953. 215 c.

Šiškov V. Jemeljan Pugatšov. 2. raamat: ajalooline jutustus. Tallinn, $1956.820 \mathrm{c}$.

Tolstoi L. Jutustused 1889-1904. Tallinn, 1958. 347 c.

\section{ЛИТЕРАТУРА}

Аванесов Р. И., Сидоров В. Н. Очерк грамматики современного русского литературного языка. Ч. 1. М.: Учпедгиз, 1945. $236 \mathrm{c}$.

Апресян Ю. Д. Избранные труды, том II. М.: Школа «Языки русской культуры, 1995.767 с. 
Бенвенист Эмиль. Природа местоимений // Общая лингвистика. М.: Едиториал УРСС, 2002. С. 285-291.

Бондарко А. В. Вид и время русского глагола. М.: Просвещение, 1971.238 с.

Бульсгина Т. В., Шмелев А. Д. Языковая концептуализация мира (на материале русской грамматики). М.: Языки рус. культуры, 1997. 576 с.

Виноградов В. В. Русский язык (грамматическое учение о слове). М.: Высшая школа, 1972. 613 с.

Гард П. Структура русского местоимения // Новое в зарубежной лингвистике. Вып. 15. М., 1985. С. 215-

226.

Герасименко Н. А. Русский язык. Местоимение. М., 2003.

Головенкина Л. Х. Местоимения в современном русском языке (функциональный аспект). Архангельск, 2004. $158 \mathrm{c}$.

Гранева И. Ю. О референтном и нереферентном употреблении местоимения мы // Вестник Нижегородского университета им. Н. И. Лобачевского. № 4. 2008. С. 206-210.

Гранева И. Ю. Местоимение мы в современном русском языке: коммуникативно-прагматический подход. Диссертация кандидата филологических наук. Нижний Новгород, 2010. 197 с.

Даниэль М. А. Является ли инклюзив местоимением первого лица (Терминологический экскурс в типологической перспективе) // Языки мира. Типология. Уралистика. Памяти Т. Ждановой. Статьи и воспоминания. M., 2002. C. 232-251.

1990. $126 \mathrm{c}$

Красильникова Е. В. Имя существительное в русской разговорной речи. Функциональный аспект. М.,

Купn-Сазонов С. Перевод - это «свой» или «чужой» текст? // Труды по русской и славянской филологии. Лингвистика. Свое-чужое в языке и речи. Tartu: Tartu Ülikooli Kirjastus, 2016. С. 296-309.

Кюльмоя И., Вайгла Э., Солль М. Краткий справочник по контрастивной грамматике эстонского и русского языков. Тарту: Tartu Ülikooli Kirjastus, 2003. 140 c.

Мурыгина 3. М. Дейктические значения личных местоимений мы, вы в русском языке // Язык и человек. M., 1970. C. 64-70.

Норман Б. Ю. Русское местоимение МЫ: внутренняя драматургия // Russian linguistics. Vol. 26. № 2. 2002. C. $217-234$.

Норман Б. Ю., Плотникова А. М. Конструкции с местоимением мы: формирование актуальной или окказиональной коллективной идентичности // Вестник № 6 (34) НГПУ, 2016. https://cyberleninka.ru/article/n/ konstruktsii-s-mestoimeniem-my-formirovanie-aktualnoy-ili-okkazionalnoy-kollektivnoy-identichnosti (дата обращения: 13.06.2019)

Русские местоимения: семантика и грамматика: межвузовский сборник научных трудов. Владимирский государственный педагогический институт имени П. И. Лебедева-Полянского. От. ред. А. Б. Пеньковский. Владимир: ВГПИ, 1989. 147 с.

Санников В. 3. Русский язык в зеркале языковой игры. М.: Языки русской культуры, 2002. 552 с.

Шелякин М. А. Русские местоимения (значение, грамматические формы, употребление): материалы по спецкурсу «Функциональная грамматика русского языка». Тарту: Тартуский государственный университет, 1986. $90 \mathrm{c}$.

Уржа А. В. Praesens historicum или dramatic present? К вопросу о терминологическом обозначении и прагматике презенсных форм в переводном нарративе // Žmogus ir Žodis. т. 17, № 3, 2015. http://www.zmogusirzodis.leu.lt/ index.php/zmogusirzodis/article/view/123/119 (дата обращения: 13.06.2019)

Blackwell S. Variations in "motherese" pronoun usage // Studies in Variation, Contacts and Change in English. Towards Multimedia in Corpus Studies, vol 2, University of Helsinki, 2007. http://www.helsinki.fi/varieng/ series/volumes/02/blackwell/ (дата обращения: 13.06.2019)

Blokland R., Kehayov P. Vene keele mõjust eesti keeles. Tagasivaateid ja perspektiive // Keele rajad. Pühendusteos professor Helle Metslangi 60. sünnipäevaks. Paths of language. Festschrift for professor Helle Metslang on the occasion of her 60th birthday. (= Eesti ja soome-ugri keeleteaduse ajakiri. Journal of Estonian and Finno-Ugric Linguistics 1-2.) Tartu: ESUKA-JEFUL, 2010. C. 35-54.

Brown P., Levinson S. Politeness: Some language universals in language use. Cambridge: Cambridge University Press, $1987.345 \mathrm{c}$.

Declerck R. The Grammar of the English Verb Phrase. The Grammar of the English Tense System, vol. 1, Berlin, New York: Mouton de Gruyter, 2006. $846 \mathrm{c}$.

Erelt M. Kõneleja ja kuulaja kaudse väljendamise võimalusi eesti keeles // Keel ja Kirjandus, 1, 1990. S. 35-39.

Gibbs W. W. Saving Dying Languages // Scientific American. 2002. Vol. 287, No. 2, 2002. P. 78-85.

Kaiser E., Hiietam K. A Typological Comparison of Third Person Pronouns in Finnish and Estonian // In A. Dahl, K. Bentzen \& P. Svenonius (ed.), Nordlyd 31(4), Proceedings of the Workshop on Generative Approaches to Finnic Languages, 2004. P. 654-667.

Kupp-Sazonov S. Grammatiline sugu - tõlkija sõber või vaenlane? // Paar sammukest XXVIII Eesti Kirjandusmuuseumi aastaraamat, Tartu: Eesti Kirjandusmuuseumi Teaduskirjastus, 2011. S. 103-126. 
Lindström L. Kõnelejale ja kuulajale viitamise vältimise strateegiad eesti keeles // Emakeele Seltsi aastaraamat. 2009. 55. S. 88-118.

Pajusalu R. Deiktikud eesti keeles. Tartu: Tartu Ülikool, 1999. 210 S.

Pajusalu R. Pronouns and reference in Estonian // STUF - Language Typology and Universals. Sprachtypologie und Universalienforschung. 2009. Vol 62, issue 1-2, 2009. P. 122-139.

Phillips K. Language and class in Victorian England. Oxford: Blackwell, 1984. 190 p.

Pool R. About the use of different forms of the first and second person singular personal pronouns in Estonia cases // Estonian: typological studies III. Publications of the Department of Estonian of the University of Tartu 11. Toim. Mati Erelt. Tartu: University of Tartu, 1999. P. 158-184.

Pyykkö R. Who is 'us' in Russian political discourse // Us and Others: Social Identities Across Languages, Discourses and Cultures. Ed. Anna Duszak, Amsterdam: Benjamins, 2002. P. 233-248.

Siewierska A. Gender Distinctions in Independent Personal Pronouns // The World Atlas of Language Structures Online. In: Dryer, Matthew S. \& Haspelmath, Martin (eds.) Leipzig: Max Planck Institute for Evolutionary Anthropology, 2013. URL: http://wals.info/chapter/44 (дата обращения: 13.06.2019)

Štšadneva V., Velman-Omelina J. Viisakusevormidest eesti- ja venekeelsetes ametlikes paralleeltekstides // Lähivõrdlusi. Lähivertailuja. 2016. 26. S. 481-500.

Wills D. D. Participant deixis in English and baby talk // Talking to Children. 1977. P. 271-298.

Поступила в редакцию 18.12.2019

Сирье Купп-Сазонов

доктор философии (PhD), лектор,

Отделение переводоведения Колледжа иностранных языков и культур

Тартуский университет

Эстония, г. Тарту, 51003, ул. Лосси, 3

e-mail: sirje.kupp-sazonov@ut.ee

\title{
S. Kupp-Sazonov \\ WHO IS THAT MYSTERIOUS WE IN RUSSIAN AND ESTONIAN? (ON THE METAPHORICAL USE OF $1^{\text {ST }}$ PERSON PLURAL FORMS)
}

\author{
DOI: 10.35634/2224-9443-2020-14-1-34-44
}

The article is devoted to the metaphorical use of $1^{\text {st }}$ person plural forms in Russian and Estonian. Personal pronouns is one of the first topics that is introduced to the learner of any language. In Russian and Estonian the systems of personal pronouns are quite similar. The essence of the $1^{\text {st }}$ person plural is primarily defined as follows: 'a speaker refers to himself or herself and somebody else'. That somebody else can be one person, many people, or even people in general. It can sometimes be very difficult to decide to whom we refers. The metaphorical use of $1^{\text {st }}$ person plural forms is not identical in Russian and Estonian. Some metaphorical uses are regular in Russian but are not common in Estonian; it depends on the cultural and linguistic traditions of the language in question.

In the paper will be analysed some cases of metaphorical use, such as 'royal we', 'authorial we', plural of modesty, 'doctoral we', 'sartorial we', 'mother's we' etc.

It is noticeable that these metaphorical uses can cause some difficulties in learning the language and also in the translation process. It can be claimed that in Russian and with some limitations also in Estonian the $1^{\text {st }}$ person plural can "replace" all the other pronouns and verb forms. It is important to keep in mind these differences between languages when teaching or translating.

Keywords: pronouns, metaphorical use, Russian, Estonian.

Citation: Yearbook of Finno-Ugric Studies, 2020, vol. 14, issue 1, pp. 34-44. In Russian.

\section{REFERENCES}

Avanesov R. I., Sidorov V. N. Ocherk grammatiki sovremennogo russkogo literaturnogo yazyka [A sketch of grammar Russian literary language]. Moscow, Uchpedgiz Publ., 1945. 236 p. In Russian.

Apresyan Yu. D. Izbrannye trudy [Selected works]. II. Moscow, Shkola Yazyki russkoi kul'tury Publ., 1995. 767 p. In Russian.

Benvenist Emil'. Priroda mestoimenii [The nature of pronouns]. Obshchaya lingvistika [General linguistics]. Moscow, Editorial URSS Publ., 2002, pp. 285-291. In Russian. 
Blackwell S. Variations in "motherese" pronoun usage - Studies in Variation, Contacts and Change in English. Towards Multimedia in Corpus Studies, University of Helsinki, 2007, vol. 2. URL: http://www.helsinki.fi/ varieng/ series/volumes/02/blackwell/ (accessed 13 June 2019). In English.

Blokland R., Kehayov P. Vene keele mõjust eesti keeles. Tagasivaateid ja perspektiive - Keele rajad. Pühendusteos professor Helle Metslangi 60. sünnipäevaks. Paths of language. Festschrift for professor Helle Metslang on the occasion of her 60th birthday. (= Eesti ja soome-ugri keeleteaduse ajakiri. Journal of Estonian and Finno-Ugric Linguistics 1-2.) Tartu: ESUKA-JEFUL, 2010, pp. 35-54. In Estonian.

Bondarko A. V. Vid i vremya russkogo glagola [Aspect and tense of Russian verb]. Moscow, Prosveshchenie Publ., 1971. 238 p. In Russian.

Brown P., Levinson S. Politeness: Some language universals in language use. Cambridge: Cambridge University Press, 1987. 345 p. In English.

Bulygina T. V., Shmelev A. D. Yazykovaya kontseptualizatsiya mira (na materiale russkoi grammatiki) [Language conceptualization of the world. (Based on Russian grammar)]. Moscow, Yazyki rus. kul'tury Publ., 1997. 576 p. In Russian.

Declerck R. The Grammar of the English Verb Phrase. The Grammar of the English Tense System, Berlin, New York: Mouton de Gruyter, 2006. vol. 1, 846 p. In English.

Gard P. Struktura russkogo mestoimeniya [The structure of Russian pronoun]. Novoe v zarubezhnoi lingvistike [New in linguistics abroad]. Moscow, 1985, vol 15, pp. 215-226. In Russian.

Gerasimenko N. A. Russkii yazyk. Mestoimenie [Russian language. Pronoun]. Moscow, 2003. In Russian.

Golovenkina L. H. Mestoimeniya v sovremennom russkom yazyke (funktsional'nyi aspekt) [Pronouns in modern Russian language (functional aspect)]. Arkhangelsk, 2004. 158 p. In Russian.

Graneva I. Yu. O referentnom i nereferentnom upotreblenii mestoimeniya my [On referential and nonreferential usage of pronoun we]. Vestnik Nizhegorodskogo universiteta im. N. I. Lobachevskogo [Bulletin of Nizhny Novgorod State University named after N.I. Lobachevsky]. 2008, vol 4, pp. 206-210. In Russian.

Graneva I. Yu. Mestoimenie my v sovremennom russkom yazyke: kommunikativno-pragmaticheskii podkhod [The pronoun we in modern Russian: a communicative and pragmatic approach. Cand. phil. sci. diss]. Nizhny Novgorod, 2010. 197 p. In Russian.

Daniel' M. A. Yavlyaetsya li inklyuziv mestoimeniem pervogo litsa (Terminologicheskii ekskurs v tipologicheskoi perspektive) [Is the first person pronoun inclusive (Terminological insight into a typological perspective)]. Yazyki mira. Tipologiya. Uralistika. Pamyati T. Zhdanovoi. Stat'i i vospominaniya. [Languages of the world. Typology. Uralistics. In memory of T. Zhdanova. Articles and memories]. Moscow, 2002, pp. 232-251. In Russian.

Erelt M. Kõneleja ja kuulaja kaudse väljendamise võimalusi eesti keeles — Keel ja Kirjandus, 1990 vol. 1, pp. 35-39. In Estonian.

Gibbs W. W. Saving Dying Languages - Scientific American, 2002, vol. 287 no. 2, pp. 78-85. In English.

Kaiser E., Hiietam K. A Typological Comparison of Third Person Pronouns in Finnish and Estonian - Proceedings of the Workshop on Generative Approaches to Finnic Languages. In A. Dahl, K. Bentzen \& P. Svenonius (ed.), 2004, Nordlyd vol 31(4), pp. 654-667. In English.

Krasil'nikova E. V. Imya sushchestvitel'noe v russkoi razgovornoi rechi. Funktsional'nyi aspekt [The noun in Russian colloquial speech. Functional aspect]. Moscow, 1990. 126 p. In Russian.

Kupp-Sazonov S. Grammatiline sugu - tõlkija sõber või vaenlane? - Paar sammukest XXVIII Eesti Kirjandusmuuseumi aastaraamat. Tartu: Eesti Kirjandusmuuseumi Teaduskirjastus, 2011, pp. 103-126. In Estonian.

Kupp-Sazonov S. Perevod - eto "svoi" ili "chuzhoi" tekst? [Is translation an 'authentic' or a 'foreign' text?]. Trudy po russkoi i slavyanskoi filologii. Lingvistika. Svoe-chuzhoe v yazyke i rechi [Works on Russian and Slavic philology. Linguistics. 'Own' and 'foreign' in language and speech]. Tartu, Tartu University Press, 2016, pp. 296-309. In Russian.

Kyul'moya I., Vaigla E., Soll' M. Kratkii spravochnik po kontrastivnoi grammatike estonskogo i russkogo yazykov [Quick Reference Guide to Contrastive Grammar of Estonian and Russian]. Tartu, Tartu University Press, 2003. 140 p. In Russian.

Lindström L. Kõnelejale ja kuulajale viitamise vältimise strateegiad eesti keeles - Emakeele Seltsi aastaraamat, 2009, vol. 55, pp. 88-118. In Estonian.

Murygina Z. M. Deikticheskie znacheniya lichnykh mestoimenii my, vy v russkom yazyke [The deictic meanings of personal pronouns we, you in Russian]. Yazyk i chelovek [Language and human]. Moscow, 1970, pp. 64-70. In Russian.

Norman B. Yu. Russkoe mestoimenie MY: vnutrennyaya dramaturgiya [The Russian pronoun my: its internal dramatics]. Russian linguistics. 2002, vol. 26, no. 2, pp. 217-234. In Russian.

Norman B. Yu., Plotnikova A. M. Konstruktsii s mestoimeniem my: formirovanie aktual'noi ili okkazional'noi kollektivnoi identichnosti [Structures with the pronoun мы: formation of actual and occasional collective identity]. Vestnik. NSPU, 2016, vol. 6 (34). In Russian. URL: https://cyberleninka.ru/article/n/konstruktsii-s-mestoimeniem-myformirovanie-aktualnoy-ili-okkazionalnoy-kollektivnoy-identichnosti (accessed 13 June 2019).

Pajusalu R. Deiktikud eesti keeles. Tartu: Tartu Ülikool, 1999. 210 p. In Estonian. 
Pajusalu R. Pronouns and reference in Estonian - STUF - Language Typology and Universals. Sprachtypologie und Universalienforschung, 2009, vol. 62, issue 1-2, pp. 122-139. In English.

Phillips K. Language and class in Victorian England. Oxford: Blackwell, 1984. 190 p. In English.

Pool R. About the use of different forms of the first and second person singular personal pronouns in Estonia cases - Estonian: typological studies III. Publications of the Department of Estonian of the University of Tartu. Ed. Mati Erelt. Tartu: University of Tartu, 1999, vol. 11, pp. 158-184. In English.

Pyykkö R. Who is 'us' in Russian political discourse - Us and Others: Social Identities Across Languages, Discourses and Cultures. Ed. Anna Duszak, Amsterdam: Benjamins, 2002, pp. 233-248. In English.

Russkie mestoimeniya: semantika i grammatika: mezhvuzovskii sbornik nauchnykh trudov [Russian pronouns: semantics and grammar: intercollegiate collection of scientific papers]. Ed. A. B. Pen'kovskii. Vladimir: VSPI, 1989. 147 p. In Russian.

Sannikov V. Z. Russkii yazyk v zerkale yazykovoi igry [The Russian Language in the Mirror of the Language Game]. Moscow, Yazyki russkoi kul'tury Publ., 2002. 552 p. In Russian.

Siewierska A. Gender Distinctions in Independent Personal Pronouns. - The World Atlas of Language Structures Online. In: Dryer, Matthew S. \& Haspelmath, Martin (eds.) Leipzig: Max Planck Institute for Evolutionary Anthropology, 2013. URL: http://wals.info/chapter/44 (accessed 13 June 2019). In English.

Štšadneva V., Velman-Omelina J. Viisakusevormidest eesti- ja venekeelsetes ametlikes paralleeltekstides Lähivõrdlusi. Lähivertailuja, 2016, vol. 26, pp. 481-500. In Estonian.

Shelyakin M. A. Russkie mestoimeniya (znachenie, grammaticheskie formy, upotreblenie): materialy po spetskursu 'Funktsional'naya grammatika russkogo yazyka' [Russian pronouns (meaning, grammatical forms, usage): materials on the special course 'Functional grammar of the Russian language']. Tartu, Tartu University Press, 1986.90 p. In Russian.

Urzha A. V. Praesens historicum ili dramatic present? K voprosu o terminologicheskom oboznachenii i pragmatike prezensnykh form $\mathrm{v}$ perevodnom narrative [Praesens historicum or dramatic present? Terminology and pragmatics of present forms in a translated narrative]. Žmogus ir Žodis. 2015, vol. 17, no. 3. In Russian. URL: http://www.zmogusirzodis.leu.lt/index. php/zmogusirzodis/article/view/123/119 (accessed 13 June 2019).

Vinogradov V. V. Russkii yazyk (grammaticheskoe uchenie o slove). [The Russian Language: Grammatical Theory of the Word]. Moscow: Vysshaya shkola, 1972. 613 p. In Russian.

Wills D. D. Participant deixis in English and baby talk — Talking to Children. 1977, pp. 271-298. In English.

Received 18.12.2019

Sirje Kupp-Sazonov, $\mathrm{PhD}$, lecturer,

Department of Translation and Interpretation Studies,

College of Foreign Languages and Cultures

University of Tartu

st. Lossi 3, 51003, Tartu, Estonia E-mail: sirje.kupp-sazonov@ut.ee 